\title{
Malind-Papua Ethnomathematics: Kandara Musical Instrument as Learning Media for Geometry Concepts in Elementary School
}

\author{
Fredy ${ }^{*}$, Lili Halimah ${ }^{2}$, Yayuk Hidayah ${ }^{3}$ \\ 1 Universitas Musamus Merauke, Indonesia, \\ 2Sekolah Tinggi Keguruan Ilmu Pendidikan Pasundan Bandung, Indonesia \\ 3Universitas Ahmad Dahlan Yogyakarta, Indonesia
}

Corresponding Author: Fredy, $\otimes$ fredy_pgsd@unmus.ac.id*

\begin{tabular}{|c|c|}
\hline & ABSTRACT \\
\hline \multirow[t]{2}{*}{$\begin{array}{l}\text { ARTICLE INFO } \\
\text { Article history: } \\
\text { Received } \\
\text { April 29, } 2020 \\
\text { Revised } \\
\text { May 11, } 2020 \\
\text { Accepted } \\
\text { May 28, } 2020\end{array}$} & $\begin{array}{l}\text { Each regions has a local culture that is the identity of the area. The } \\
\text { Malind (Anim } \mathrm{Ha} \text { ) tribe as the original tribe of Merauke has a musical } \\
\text { instrument that has a copyright kandara. Kandara was used as a musical } \\
\text { accompaniment of dances and songs at traditional ceremonies. Kandara } \\
\text { can be used as a learning media for the concept of geometry in } \\
\text { elementary schools. This article aimed to describe the instrument of the } \\
\text { musical instrument as an ethnomatematics of the Malind-Papua tribe that } \\
\text { can be used as a learning medium for geometrical concepts in elementary } \\
\text { schools. It was qualitative research using the ethnographic approach. } \\
\text { Sampling using a cluster random sampling technique. The results } \\
\text { showed that ethnomatematics were found in parts of the kandara such as } \\
\text { the handle or hands of the kandara, head, body or middle part and the tail } \\
\text { of the kandara. Secondly, the musical instrument of kandara can be used as } \\
\text { a learning medium to explain the concepts of geometry in elementary } \\
\text { school in the form of the concept of angles, flat shapes (triangles, } \\
\text { rectangles and circles) and building spaces (incised cones and tubes). } \\
\text { Thirdly, ethnomatematics can be a learning material in elementary } \\
\text { schools based on local culture, not only can help students understand } \\
\text { mathematical concepts well but also maintain and respect the cultures of } \\
\text { local communities (Malind tribe as an indigenous of Merauke). }\end{array}$ \\
\hline & Keywords: Ethnomathematics, Kandara, Learning Media, Geometry Concepts \\
\hline How to cite & $\begin{array}{l}\text { Fredy, F., Halimah, L., \& Hidayah, Y. (2020). Malind-Papua Ethnomathematics: } \\
\text { Kandara Musical Instrument as Learning Media for Geometry Concepts in } \\
\text { Elementary School. Jurnal Iqra' : Kajian Ilmu Pendidikan, 5(1). 43-57. } \\
\text { https://doi.org/10.25217/ji.v5i1.872 }\end{array}$ \\
\hline $\begin{array}{l}\text { Journal Homepage } \\
\text { This is an open acces }\end{array}$ & $\begin{array}{l}\text { http://journal.iaimnumetrolampung.ac.id/index.php/ji/ } \\
\text { ticle under the CC BY SA license }\end{array}$ \\
\hline & $\begin{array}{l}\text { https://creativecommons.org/licenses/by-sa/4.0/ } \\
\text { Institut Agama Islam Ma'arif NU (IAIMNU) Metro Lampung }\end{array}$ \\
\hline
\end{tabular}

\section{INTRODUCTION}

Culture is born from the habits and interactions of certain people with their environment. The multicultural conditions of certain communities that differ in cultures in certain regions. Indonesia as an archipelago has a unique cultural diversity in each region. Papua itself has a distinctively different culture between each tribe inhabiting the region. One of them is the Malind tribe with a unique musical instrument called kandara. Malind tribe as an indigenous tribe of Merauke has approved the kandara or commonly known as Tifa as a typical musical instrument of Merauke through copyright granted by 
the Netherlands government in 2019 (Prihandoko et al., 2019). Kandara is stored in the Leiden Museum in the Netherlands. Kara is a three-dimensional work of art and is categorized as a cultural object.

Preservation of culture is most effective through the education route because it has a close and complementary relationship between one another. Cultural values contained in a culture can be transferred through education and learning in the classroom. Learning will learn through culture can help students discuss and appreciate their own culture (Supriyadi et al., 2020). In addition, it can increase creativity, respect self-esteem, and mutual respect, and offer a broad view of help (D'Ambrosio \& Rosa, 2016). Ethnomathematics is closely related to daily life, therefore children will more easily discuss the material if departing from their contextual and cultural problems (Zaenuri \& Dwidayati, 2018; Rahayu et al., 2019). Before it is applied in education and learning in the classroom, it needs to be studied to determine the ideas/understanding contained in the culture. The study is known as ethnomathematics.

Special ethnomathematics has long been introduced by D'Ambrosio in 1977 by introducing leadership linking mathematics in socio-cultural life. Everything in humans contains mathematical ideas in it. These activities such as counting, finding, measuring, playing games and designing (Septianawati et al., 2017). The purpose of ethnomathematics is to refute mathematical facts or concepts from various points of view and to respect the rights and culture of everyone (Fouze \& Amit, 2018). Another goal is to involve the link between mathematics and culture so that students' perceptions of mathematics become more appropriate and mathematics learning can be more adapted to the cultural context of students and society (Ditasona, 2018). Exploration to classify activities containing mathematical concepts is very helpful in learning culturebased mathematics. This study are the geometry contained in the musical instrument kandara. These elements include the concept of angles, plane (geometry), and solid (geometry). The concept of angle is found at right angles that form the handle of the kandara. Plane (geometry) such as rectangles, triangles, and circles are found in patterns and paintings. Solid (geometry) such as cylinder and frustum of a cone on the head, tail, and body of the kandara. These findings can be used as a material for geometry learning media in elementary schools. During geometry, material is difficult for students to understand because teachers use formal mathematics in their learning. Students' expectations in answering geometry do not match the expectations expected in learning geometry (Roza et al., 2017). While students are able to understand mathematical concepts will benefit their lives. Mathematics provides an opportunity to practice the ability to think and ultimately be able to develop their intellectual abilities (Syafitri et al., 2018). Therefore, teachers are required to be able to design learning media that are able to provide student learning and concretize something abstract (Mudinillah, 2019).

There have been many previous studies that discussed learning outcomes of using learning media, such as how to count Arfak tribes in Indonesia using Hatam (Haryanto et al., 2017). It can be used as learning media for addition or 
aid of integers. Likewise, the concepts of numbers and symbols, graphics, logic, and opportunities that exist in the culture of the Inuit, Navajo, and Iroquois from North America and the theory of permutations and combinations in the book Alam Al-Hussab and Raudah Al-Hussab in Malaysian Malay Islam (Ismail \& Ismail, 2010). It can be used as a learning medium for introducing statistics. The concept of measurement, area, volume, and pattern in the Yogyakarta palace (Mauluah \& Marsigit, 2019) can be used as a learning medium for geometry. In the style of musical instruments, Marawis found mathematical practices, such as geometric shapes in the form of circles and mathematical concepts in the form of reflection, translation, folding symmetry, rotary symmetry, acute angles and obtuse angles (Marina \& Izzati, 2019). This research proves the existence of mathematical concepts contained in a culture, making it possible to be developed in learning mathematics in elementary schools. Based on these results, kandara musical instrument as the local wisdom of the people of MalindPapua can be traced without the mathematics contained therein. From its shape, kandara musical instrument contains the concept of geometry in it, agreed upon the concept of angles, building flat, building space. This concept is a concept that is discussed in elementary schools. The results of the search for the concept of geometry are expected to be a medium for learning mathematics in elementary schools based on local culture.

\section{METHODS}

The researchers used descriptive qualitative method (Willis, D. G et all., 2016; Grove, S. K., \& Gray, J. R, 2018). Descriptive method applied to describe the results of Malind-Papua ethnomathematics exploration in the form of elementary school geometry concepts contained in musical instruments made from milk tree trunks. This research uses an ethnographic approach (Randall, D., \& Rouncefield, M, 2018; Skinner, J et all., 2013). Observation and participatory observation techniques were chosen so that the researcher could participate directly with the object taken. Withdrawing the sample using a cluster random sampling technique. The researcher acts as a human instrument. The consequence is the position of the researcher who cannot be represented by others. The researcher compiles the plan, selects the correspondence as a source of data, collects and collects data, makes interpretation of the data, and draws conclusions on his findings. Interview guides are used to get findings on the desired goals. The data obtained is then made to look for the geometrical concepts contained in the kandara musical instrument. Next look for a universal relationship between culture and mathematics (ethnomathematics). The researcher also explored further if there are sub-parts of the musical instrument and then presented in the picture presented the connection between the concept and the musical instrument. 


\section{RESULT AND DISCUSSION}

The Malind tribe (Anim $\mathrm{Ha}$ ) opens their artistic life through musical instruments, paintings, and dancing. Every important moment such as traditional ceremonies, approval of sasi, giving clan (inisiasi) and death, the sound of kandara always accompanies the activity. Kandara musical instrument is made from blackboard tree (kayu susu) with a latin name alstonia scholaris L., trunks which are perforated in the middle and left empty. The blackboard tree (kayu susu) was chosen because the trunk is light and not too hard. The selected blackboard trees that have a diameter of $30-40 \mathrm{~cm}$ or according to the amount of the kandara to be made. In addition to blackboard trees, kandara can also use other trees such as hibiscus, candlenut and gempol trees. The upper part (head) is made of leather made from kangaroo skin (saham), monitor lizard skin or snakeskin (patola). Before it is used to close, the skin is dried by drying. The size of the kandara itself is adjusted to the height of the person wearing it. The highest limit is the adult chin.

Figure 1. Blackboard Tree (kayu susu) as Material for Making Kandara
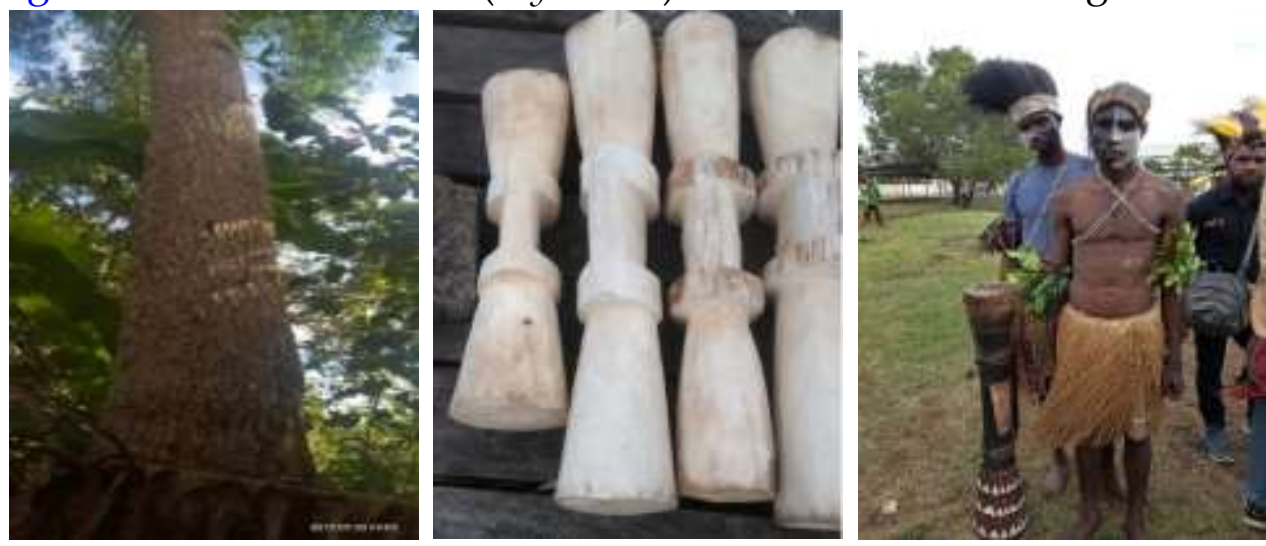

This study found several geometric concepts in musical instruments that can be used as learning materials in elementary school mathematics based on local culture. Geometry is a branch of mathematics that does not prioritize relationships between numbers, even though there are numbers in it, but geometry studies the relationships between points, lines, angles, fields, twodimensional and three-dimensional figure. There are two types of geometry that are studied in elementary school, namely two-dimensional and threedimensional geometry. Two-dimensional geometry is geometric that consists of only two dimensions (length and width), or only have area but does not have volume, while three-dimensional geometry is a three-dimensional geometric shape (length, width, and height) or that has volume (Ulum, 2018).

Mathematics subjects are given at the elementary level in addition to getting mathematics itself, as well as to develop logical, analytical, systematic, critical, creative thinking patterns of students and develop patterns of collaborative habits in problem-solving. This competency is needed by students in developing the ability to find, obtain, manage and use information based on the concept of scientific logical thinking to survive in an uncertain life (Farah \& 
Budiyono, 2018). Broadly speaking, the standard of mathematics competence in elementary schools related to the concept of geometry contained in musical instruments can be seen in Table 1 below.

Table 1. Mathematics Competency Standards in Elementary School

Related to Geometry Concepts

\begin{tabular}{|l|l|l|}
\hline $\begin{array}{c}\text { Section on musical } \\
\text { instruments kandara }\end{array}$ & \multicolumn{1}{|c|}{$\begin{array}{c}\text { Geometry } \\
\text { concepts }\end{array}$} & \multicolumn{1}{c|}{$\begin{array}{c}\text { Mathematical competency } \\
\text { standards } \\
\text { in elementary school }\end{array}$} \\
\hline $\begin{array}{l}\text { hand / handle } \\
\text { paint }\end{array}$ & $\begin{array}{l}\text { right angle } \\
\text { triangles, } \\
\text { rectangles and } \\
\text { circles } \\
\text { frustum of a } \\
\text { cone } \\
\text { cylinder }\end{array}$ & $\begin{array}{l}\text { identify the shape of the flat and the } \\
\text { shape of space according to nature, } \\
\text { elements, or congruence }\end{array}$ \\
body/centre & $\begin{array}{l}\text { estimate the size (for example: } \\
\text { length, area, volume) of an object or } \\
\text { geometry }\end{array}$ \\
\hline
\end{tabular}

\section{Angular and plane (geometry) concept}

Typical of the Malind tribal kandara is to have a handle/hand in the middle. This is to make it easier for users to hit kandara. The size of the handle follows the large body/middle part of the kandara. An angular concept can be seen from the right angle formed between the handle and the center of the kandara. Plane concept tracing is found in the painting in kandara. The painting aims to beautify the appearance of kandara. Also as a sign of ownership in each clan kandara. By looking at the painting, you can find out the origin of the kandara ownership. The Malind tribe recognize three colors in the painting patterns of Kandara namely red, white and black. Making these colors from natural ingredients. The black color comes from charcoal or black mud mixed with bark that is burned then stirred with water or animal blood. The red color comes from red clay (kaise epe) which is pounded and given water, while the white color comes from snail shells or shells which are pounded until it becomes powder (Supriyadi \& Nurvitasari, 2019). The shape of the candlestick painting contains the concept of a triangle, rectangle and circle shape as in the following figure 2 .

Figure 2. The Concept of Flat Figure in the Candlestick Pattern: section (i). triangle; section (ii). rectangle; section (iii). circle

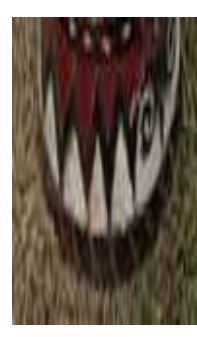

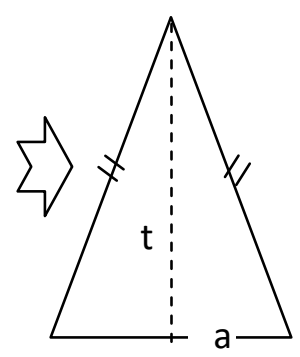

(i)

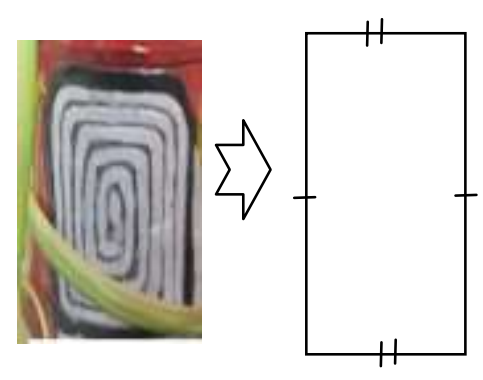

(ii)

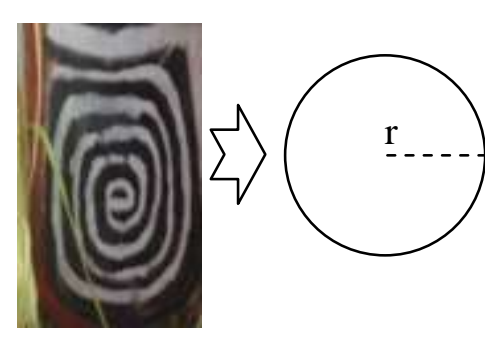

(iii) 
The style of painting in part (i) depicts a triangle that is a flat shape formed by three sides in the form of a straight line and has three angles. Besides having 3 sides or ribs and angles, the properties possessed by the triangle have a large angle of $180^{\circ}$. The candlestick forms an isoceles triangle. Is a triangle whose two sides are the same length and have two equal angles. If $a$ is the base and $t$ is height then the area and circumference of the isosceles triangle can use the following formula.

$$
\text { area } \begin{aligned}
\Delta & =2 \times\left(\frac{1}{2} \cdot a . t\right) \\
& =a \times t
\end{aligned}
$$

circumference $\Delta=$ side $\mathrm{x}$ side $\mathrm{x}$ side

The concept of a flat shape in part (ii) is a rectangle that has the sides facing the same length and has four angles. In addition to having sides that are facing the same length and four angles with the same large angle of $90^{\circ}$, the square has other properties that have four diagonal sides that are the same length, have 3 folding symmetries, have two rotary symmetries. If $p$ is length and $l$ is width then width and circumference:

$\begin{array}{ll}\text { area } & =p \times l \\ \text { circumference } & =2 \cdot(p+l) \\ \text { diagonal length } & =\sqrt{p^{2}+l^{2}}\end{array}$

In section (iii) the candlestick pattern contains the concept of a circle which is a set of all points on a plane within a certain distance called the radius of a point called the center. Some circle properties are having infinite rotational symmetry, having folding symmetry and infinite axis, having no vertices and having one side. If $\Pi=3.14$ or $\frac{22}{7}, r$ is the radius and $d$ is the diameter $(2 \times \mathrm{r})$,

then the formula for area and circumference of a circle is as follows.

Area circle $\quad=\Pi \times \mathrm{r}^{2}$

circumference circle $=2 \Pi \times \mathrm{d}$

\section{Solid (geometry) concept}

Kandara consists of three parts, namely the head, middle and tail. On the head there is a cover made of dried kangaroo (stock) leather. This is the part that is hit and to get the desired sound you can add a lump of honey that has been heated. The number of honey clumps affects the sound produced. The more lumps of honey are given, the more loud the sound is produced. Also the head must be smaller than the tail with a ratio of 45 : 50. At the tail the painting is given with the aim of beautifying the appearance of the kandara. Figure 3 gives an overview of the geometrical concepts found in the tail and head of the kandara.

Section (i) is part of the head and tail of kandara which contains frustum of a cone concept. Section (ii) above consists of two cones namely a large cone and a small cone, the small cone is called the section/piece of the large cone, where the large cone has radius $R$, length of the painter s and height $t$. The small cone 
has radius $r$, length of painter $s$ and height $t_{1}$ and $\mathrm{R}>\mathrm{r}$. From section (ii) obtained:

$\mathrm{s}=\mathrm{s}_{1}+\mathrm{s}_{2}$

$\mathrm{t}=\mathrm{t}_{1}+\mathrm{t}_{2}$

Figure 3. The Concept of a Cone Stuck to the Tail and Head of the Kandara: Part (i). The Tail and Head of the Kandara; section (ii). frustum of a cone concept

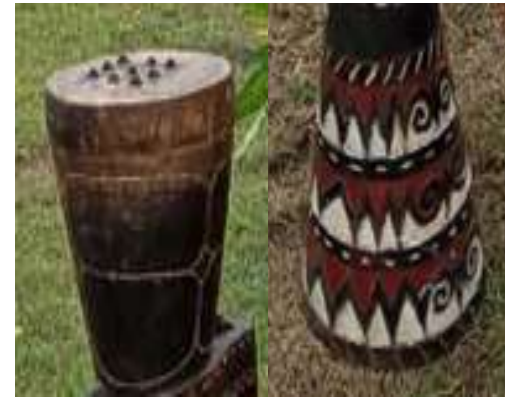

(i)
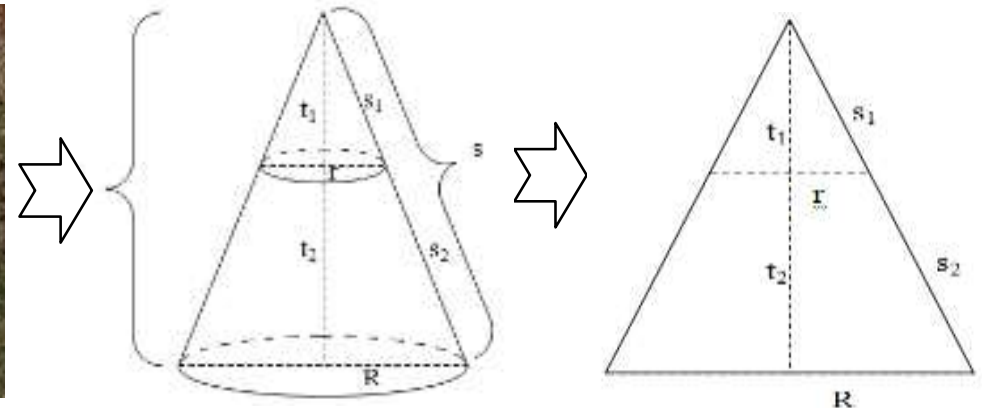

(ii)

in part (iii) fulfilling the concept of congruence in the triangle also obtained:

$$
\begin{aligned}
& \frac{t}{t_{1}}=\frac{R}{r} \\
& \frac{t_{1}+t_{2}}{t_{1}}=\frac{R}{r} \\
& \mathrm{r}\left(\mathrm{t}_{1}+\mathrm{t}_{2}\right)=\mathrm{t}_{1} \mathrm{R} \\
& \mathrm{t}_{1} \mathrm{r}+\mathrm{t}_{2} \mathrm{r}=\mathrm{t}_{1} \mathrm{R} \\
& \mathrm{t}_{1} \mathrm{R}-\mathrm{t}_{1} \mathrm{r}=\mathrm{t}_{2} \mathrm{r} \\
& \mathrm{t}_{1} \mathrm{R}-\mathrm{r}=\mathrm{t}_{2} \mathrm{r} \\
& \mathrm{t}_{1}=\frac{r t_{2}}{R-r}
\end{aligned}
$$

By using the pythagorean theorem, $\mathrm{s}_{2}, \mathrm{~s}_{1}$ and s are obtained:

$$
\begin{array}{ll}
\mathrm{S} 2 & =\sqrt{(R-r)^{2}+t_{2}{ }^{2}} \\
\mathrm{~S} 1 & =\frac{r}{R-r} s_{2} \\
\mathrm{~S} & =\frac{R}{R-r} s_{2}
\end{array}
$$

frustum of a cone blanket area:

$=$ large cone area - small cone area

$=\Pi \mathrm{Rs}-\Pi \mathrm{r} \mathrm{s} 1$

$=\Pi(\mathrm{R} \mathrm{s}-\mathrm{rs} 1)$

$=\Pi\left(\mathrm{R} \frac{R}{R-r} s_{2}-\mathrm{r} \frac{r}{R-r} s_{2}\right)$

$=\Pi\left(\frac{R^{2}}{R-r} s_{2}-\frac{r^{2}}{R-r} s_{2}\right.$

$=\Pi S_{2} \frac{(R+r)(R-r)}{R-r}$

$=\Pi s_{2}(\mathrm{R}+\mathrm{r})$

frustum of a cone volume:

$=$ large cone area - small cone area 


$$
\begin{aligned}
& =\frac{1}{3} \Pi R^{2} \mathrm{t}-\frac{1}{3} \Pi r_{1}^{2} t_{1} \\
& =\frac{1}{-3} \Pi\left(R^{2} \mathrm{t}-r_{1}^{2} t_{1}\right) \\
& =\frac{1}{3} \Pi\left(R^{2}\left(t_{1}+t_{2}\right)-r_{1}^{2} t_{1}\right) \\
& =\frac{1}{3} \Pi\left(R^{2} t_{1}+R^{2} t_{2}-r_{1}^{2} t_{1}\right) \\
& =\frac{1}{3} \Pi\left(R^{2}\left(t_{1}-r_{1}^{2} t_{1}+R^{2} t_{2}\right)\right. \\
& =\frac{1}{3} \Pi\left(t_{1}\left(R^{2}-r^{2}\right)+R^{2} t_{2}\right) \\
& =\frac{1}{3} \Pi\left(\frac{r t_{2}}{R-r}(R+r)(R-r)+R^{2} t_{2}\right) \\
& =\frac{1}{3} \Pi\left(\mathrm{r} t_{2}(R+r)+R^{2} t_{2}\right) \\
& =\frac{1}{3} \Pi\left(R r t_{2}-r^{2} t_{2}+R^{2} t_{2}\right) \\
& =\frac{1}{3} \Pi t_{2}\left(R^{2}+R r+r^{2}\right)
\end{aligned}
$$

So, it can be concluded if there is a cone beheaded to the length of the base radius $R$, the upper radius $r$, height $t$ and length of the painter's line $s$. Then, we can determine the area of the cone blanket and the volume of the cone cone with the formula:

frustum of a cone blanket area $=\Pi s_{2}(\mathrm{R}+\mathrm{r})$

frustum of a cone volume

$$
=\frac{1}{3} \Pi t_{2}\left(R^{2}+R r+r^{2}\right)
$$

Another case with the center of cylinder-shaped kandara with empty space in it. In this section there is a hand that functions as a handle kandara. Figure 3 gives an illustration of the tube concept in the middle of the kandara.

Figure 3. Cylinder Concept in the Middle of the Kandara

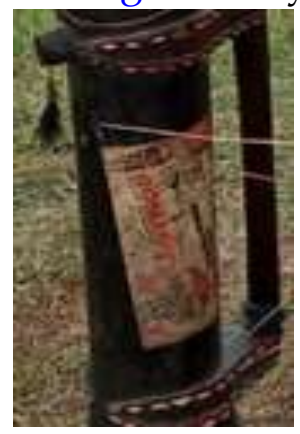

(i)

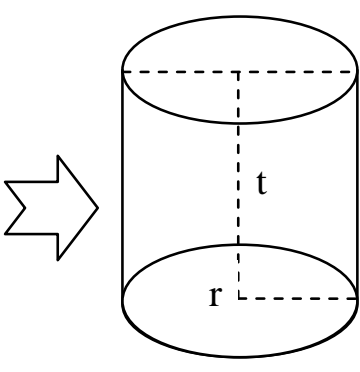

(ii)

Part (i) is the middle part of the kandara containing cylinder concept. Section (ii) provides an illustration that the cylinder surface area can be seen in the tube nets consisting of a rectangular area and two congruent circular regions. The rectangular area is the same length as the circumference of the base/top circle of the tube, while the width is the same as the height of the tube. The area of this rectangle is called the area of the curve of the tube. If $r$ is the radius of the tube and $t$ is the height of the cylinder, then:
curved cylinder
$=$ rectangular area 


$$
\begin{aligned}
& =\mathrm{p} \times 1 \\
& =\text { circumference circle } x \text { height cylinder } \\
& =(2 \Pi \mathrm{t}) \times(\mathrm{t}) \\
& =2 \Pi \mathrm{rt} \\
& =\text { total area of the side of the cylinder } \\
& =\text { curved cylinders }+2 \text { base circle area } \\
& =2 \pi \mathrm{rt}+2\left(\Pi \mathrm{r}^{2}\right) \\
& =2 \pi \mathrm{r}(\mathrm{r}+\mathrm{t})
\end{aligned}
$$

Basically the cylinder is a prism because the base plane and the upper plane of the cylinder are parallel and congruent. Thus the volume of the cylinder is equal to the volume of the prism that is the area of the base times high. Because the cylindrical base is circular, the volume of the cylinder is stated as follows:

$$
\begin{aligned}
\text { cylinder volume } & =\text { base area } \mathrm{x} \text { height } \\
& =\pi r^{2} \times \mathrm{t} \\
& =\pi r^{2} \mathrm{t}
\end{aligned}
$$

After finding the area and volume of frustum of a cone in the head of the kandara, then the area and volume of the cylinder in the middle of the kandara, we can determine the overall area and volume of the kandara by adding up the head, middle and tail of the kandara. Figure 4 below provides an overview of the area and volume of candlestick harmony.

Figure 4. Total Area and Volume of Kandara

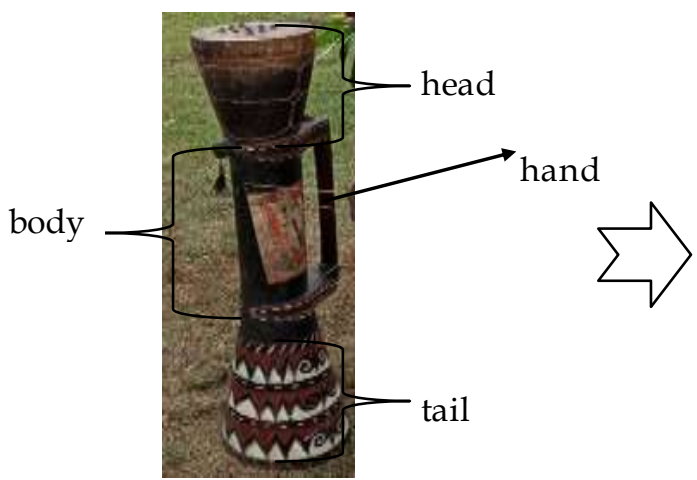

(i)

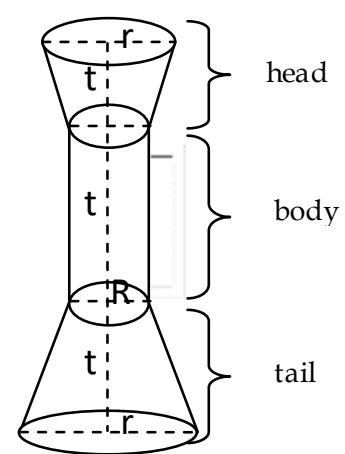

(ii)

$$
\begin{aligned}
\text { Total area of Kandara } & =\text { head area }+ \text { body area }+ \text { tail area } \\
& =\Pi s_{2}\left(\mathrm{R}+\mathrm{r}_{2}\right)+2 \Pi \mathrm{R}(\mathrm{R}+\mathrm{t})+\Pi s_{1}\left(\mathrm{R}+\mathrm{r}_{1}\right) \\
\text { Total volume of Kandara } & =\text { head volume }+ \text { body volume }+ \text { tail volume } \\
& =\frac{1}{3} \Pi t_{2}\left(R^{2}+R r_{2}+r_{2}^{2}\right)+\Pi \mathrm{R}^{2} \mathrm{t}+\frac{1}{3} \Pi t_{1}\left(R^{2}+R r_{1}+r_{1}^{2}\right)
\end{aligned}
$$

Based on search results based on knowledge of mathematical material that can be explored in a culture. This is because mathematics is cultural products so the development of mathematics will not be separated from development of existing culture. Adding, the level of mathematical knowledge grows and has implications for how mathematics influences cultural development to achieve a civilization (Muhtadi et al., 2017). Ethnomathematics-based mathematics 
learning that implements local culture can change people's perceptions about the application of mathematics in everyday life (Fredy, Lieung, et al., 2019; Widada et al., 2018). It is expected that with ethnomathematics based learning, students can not only understand mathematical concepts well but can also support and preserve their local culture.

\section{Musical instruments as learning media mathematics}

Geometry thinking and visual thinking are essential in art, design, graphics, animation and various other vocational fields. The introduction of geometry as a basic ability in mathematics has long been obtained in the elementary curriculum lately. The rationale is a geometry that is closely related to our daily lives. Both practical aspects and beauty (aesthetics) can be found in the fields of art and architecture, space planning, home planning, building planning, clothing design (fashion) and car design. Topics that can interest students and can also be used to develop knowledge of geometry, student skills and problem-solving (Yeni, 2011). In culture responsive learning, mathematics teachers are expected to be able to realize mathematics as a science that is inherent in culture. For this reason, teachers also need to discuss the social and cultural backgrounds of their students. The teacher needs to have knowledge about the local culture related to mathematics, understand the mathematical knowledge obtained by students from daily activities and have the skills to develop and develop mathematics learning using culture.

It is not new to include ethnomathematics in the curriculum, consisting of various tribes and cultures, and each tribe in Indonesia has a special way of resolving the resulting problems. One application of which is also still commonly combined using scientific is ethnomathematics (Sumiyati et al., 2018). Learning culture-based mathematics (ethnomathematics) does not mean making the subject of primitive society or being returned to the past. But how can a culture that has become an original character survive with its time and time (Supriadi et al., 2016). Ethnomatemics develop local wisdom so that it can motivate students in learning mathematics (Fajriyah, 2018). This is because students will be happy if they learn about their culture.

The main findings in this study are musical instruments that contain the concept of geometry in it. This concept is one of the mathematical materials provided in elementary schools. The concept of angles can be learned with observed the handle of the kandara. The concept of the plane (geometry) with its properties such as triangles, rectangles, and circles can be learned with observed the patterns and paintings. Likewise, the concept of the cylinder can be learned with observed part of body the kandara, while the concept frustum of a cone can be learned using the head and tail of the kandara. Learning by using musical instruments as a culture-based learning media will help students in learning mathematics. Students can further explore their knowledge by understanding and measuring each part of the candidate. After that, they can determine the area and volume of the kandara. Therefore, the integration of culture-based learning into learning can be a solution in helping students to 
understand mathematical concepts that support in school (Andriyani \& E, 2017).

The results of this study have relevance to previous research as conducted by Sroyer et al., (2018) concluding that geometrical concepts such as trapezoid, rectangle, ellipse and frustum of a cone in traditional houses and the musical instruments Tifa from the tribe of Biak Similar to the research of Lubis et al., (2018), the concept of arithmetic and geometry such as the cylinder and frustum of a cone can be learned from in the musical instrument Gordang Sambilan from the tribe of Mandailing. What distinguishes it from the results of the study is that the structure of the musical instrument consists of two frustum of a cone and one cylinder section while their research has only one part of the frustum of a cone and one part of the cylinder. Another case with Febriyanti et al., (2018) research, which revealed the concept of the plane (geometry) such as tangular, rectangular and semicircular and the concept of the cylinder can be learned through the traditional crank and gasing game of the Sundanese tribe. Hardiarti (2017) added that the concept of rectangular can also be learned from the structure of the Muaro Jambi temple, while the triangle concept can be learned from the carvings of the Toraja tribe (Trandililing, 2015). The results of this previous study prove that the concept of mathematics especially geometry is indeed contained in a culture, making it possible to be integrated with learning mathematics in elementary schools. The results of this study focus on the discovery of materials that can be developed into geometry learning media in elementary schools, especially in material angles, planes (geometry), and solid (geometry). The implication of this research is the use of musical instruments in the field of education one of them through learning media to explain the concept of geometry in elementary schools. Students can play kandara to develop their mathematical thinking. Students can also develop problem-solving strategies to look for patterns and geometry rules contained in the kandara. The use of musical instruments kandara is expected to be a medium of learning mathematics in elementary schools to bridge the students' understanding of concrete things to abstract.

\section{CONCLUSIONS}

Based on the research findings and discussion, it can be concluded that the concept of geometry is found in parts of the kandara. The holding part of the kandara can explain the concept of right angles, the middle part explains the concept of the cylinder, the head and tail part explains the frustum of a cone. In addition, the painting and pattern of kandara can explain the material of flat figure such as triangles, rectangles and circles. As a result of this research, it is hoped that the musical instruments of kandara can become learning media in ethnomathematics-based elementary schools. Students will better understand mathematical concepts by using media that are close to their daily lives or have a relationship with their own culture. It is also a good thing in attracting and preserving the Malind tribe culture as an indigenous of Merauke. 


\section{ACKNOWLEDGEMENTS}

Thanks for the Rector Universitas Musamus for guidance who has given motivation to author to immediately complete this research. All parties involved in this study. This research was funded by DIPA No. SP DIPA.042.01.2.401023/2019 revision 04 of 23 July 2019 In accordance with the Internal Research Contract of Universitas Musamus, No. 261.13/UN52.8/LT/2019, 9 September 2019.

\section{AUTHOR CONTRIBUTION STATEMENTS}

Fredy $(\mathrm{F})$ was the main author in this article. Lili Halimah (LH) and Yayuk Hidayah $(\mathrm{YH})$ helps researchers to evaluate this research. The authors approved this manuscript as a result of research carried out in the Malind tribal community. The hope is that research will contribute to the development of ethnomathematics-based mathematics learning media in elementary schools.

\section{REFERENCES}

Andriyani, \& E, K. (2017). Etnomatematika: Model Baru dalam Pembelajaran. Jurnal Gantang, II(2), 133-144. Google Scholar.

D'Ambrosio, U., \& Rosa, M. (2016). Ethnomathematics and Its Pedagogical Action. 13th International Congress on Mathematical Education, July, 24-31. Google Scholar.

Ditasona, C. (2018). Ethnomathematics Exploration of the Toba Community: Elements of Geometry Transformation Contained in Gorga (Ornament on Bataks House). IOP Conference Series: Materials Science and Engineering, 335(1). https:/ / doi.org/10.1088/1757-899X/335/1/012042

Fajriyah, E. (2018). Peran Etnomatematika Terkait Konsep Matematika dalam Mendukung Literasi. PRISMA: Prosiding Seminar Nasional Matematika, 1, 114-119. Google Scholar.

Farah, R., \& Budiyono, B. (2018). Pembelajaran Matematika Materi Geometri di SD Al Hikmah Surabaya. Jurnal Penelitian Pendidikan Guru Sekolah Dasar, 6(3), 254923. Google Scholar

Febriyanti, C., Prasetya, R., \& Irawan, A. (2018). Etnomatematika Pada Permainan Tradisional Engklek Dan Gasing Khas Kebudayaan Sunda. Barekeng: Jurnal Ilmu Matematika Dan Terapan, 12(1), 1. https://doi.org/10.30598/vol12iss1pp1-6ar358

Fouze, A. Q., \& Amit, M. (2018). Development of mathematical thinking through integration of ethnomathematic folklore game in math instruction. Eurasia Journal of Mathematics, Science and Technology Education, 14(2), 617630. https:/ / doi.org/10.12973/ ejmste/ 80626

Fredy, Lieung, K. W., Butarbutar, R., \& Duli, A. (2019). Science process skills in learning environmental pollution using PBL models. IOP Conference Series: Earth and Environmental Science, 343(1). https://doi.org/10.1088/17551315/343/1/012179

Grove, S. K., \& Gray, J. R. (2018). Understanding Nursing Research E-Book: Building an Evidence-Based Practice. Elsevier Health Sciences. Google Scholar 
Hardiarti, S. (2017). Etnomatematika: Aplikasi Bangun Datar Segiempat pada Candi Muaro Jambi. Aksioma, 8(2), 99-110. https:// doi.org/10.26877/aks.v8i2.1707

Haryanto, Nusantara, T., Subanji, \& Rahardjo, S. (2017). Ethnomathematics In Arfak West Papua-Indonesia Numeracy Of Arfak. International Journal of Scientific \& Technology Research, 06(09), 325-327. Google Scholar

Ismail, M. R., \& Ismail, H. (2010). Exploring Malay-Islamic ethnomathematics: Al-Khatib's combinatoric theory in Àlam Al-Hussab And Raudah AlHussab. International Conference on Mathematics Education Research 2010 $\begin{array}{llll}\text { (ICMER 2010) Exploring, } & \text { 8(5), }\end{array}$ https:// doi.org/10.1016/j.sbspro.2010.12.102

Lubis, S. I., Mujib, A., \& Siregar, H. (2018). Eksplorasi Etnomatematika pada Alat Musik Gordang Sambilan. Edumatika: Jurnal Riset Pendidikan Matematika, 1(2), 1. https:// doi.org/10.32939/ ejrpm.v1i2.246

Marina, M., \& Izzati, N. (2019). Eksplorasi Etnomatematika pada Corak Alat Musik Kesenian Marawis sebagai Sumber Belajar Matematika. Jurnal Gantang, 4(1), 39-48. https:/ / doi.org/10.31629/jg.v4i1.1027

Mauluah, L., \& Marsigit. (2019). Ethnomathematics for elementary student: Exploration the learning resources at kraton Yogyakarta. International Journal of Scientific and Technology Research, 8(7), 776-780. Google Scholar.

Mudinillah, A. (2019). The Development of Interactive Multimedia Using Lectora Inspire Application in Arabic Language Learning. Jurnal Iqra': Kajian Ilmu Pendidikan, 4(2), 285-300. https:/ / doi.org/10.25217/ji.v4i2.570

Muhtadi, D., Sukirwan, Warsito, \& Prahmana, R. C. I. (2017). Sundanese ethnomathematics: mathematical activities in estimating, measuring, and making patterns. Journal on Mathematics Education, 8(2), 352-365. https:/ / doi.org/10.1017/cbo9780511600036.030

Supriyadi, S., \& Nurvitasari, E. (2019). Inventarisasi Sains Asli Suku Malind: Upaya Dalam Pengembangan Kurikulum Ipa Kontekstual Papua Berbasis Etnosains. Edu Sains: Jurnal Pendidikan Sains dan Matematika, 7(1), 10-20. https:// doi.org/10.23971/eds.v7i1.1081

Prihandoko, L. A., Tembang, Y., Marpaung, D. N., \& Rahman, F. (2019). English language competence for tourism sector in supporting socio-economic development in Merauke: A Survey Study. IOP Conference Series: Earth and Environmental Science, 343(1). https://doi.org/10.1088/17551315/343/1/012170

Rahayu, D. P., Lieung, K. W., \& Fredy. (2019). The use of reading material based contextual approach to improve environmental concern attitude of elementary school students. IOP Conference Series: Earth and Environmental Science, 343(1). https:/ / doi.org/10.1088/1755-1315/343/1/012225

Randall, D., \& Rouncefield, M. (2018). Ethnographic Approach to Design. The Wiley Handbook of Human Computer Interaction Volume, 125. Google Scholar

Roza, Y., Yuanita, P., Saragih, S., Alfajri, H., \& Saputra, A. (2017). ComputerBased Media for Learning Geometry at Mathematics Class of Secondary $\begin{array}{lllll}\text { Schools. Journal of Educational Sciences, } & 1(1), \quad 79 .\end{array}$ 
https:/ / doi.org/10.31258/jes.1.1.p.79-91

Skinner, J. (Ed.). (2013). The interview: An ethnographic approach (Vol. 49). A\&C Black. Google Scholar

Trandililing, P. (2015). Etnomatematika Toraja (Eksplorasi Geometri Budaya Toraja). Jurnal Imiah Matematika Dan Pembelajarannya, 1(2), 47-57. Google Scholar.

Septianawati, T., Turmudi, \& Puspita, E. (2017). Ethnomathematics study: uncovering units of length, area, and volume in Kampung Naga Society. Journal of Physics: Conference Series, 755(1-8). https:/ / doi.org/10.1088/17426596/755/1/011001

Sroyer, A. M., Nainggolan, J., \& Hutabarat, I. M. (2018). Exploration of Ethnomathematics of House and Traditional Music Tools Biak-Papua Cultural. Formatif: Jurnal Ilmiah Pendidikan MIPA, 8(3), 175-184. https:/ / doi.org/10.30998/ formatif.v8i3.2751

Sumiyati, W., Netriwati, N., \& Rakhmawati, R. (2018). Penggunaan Media Pembelajaran Geometri Berbasis Etnomatematika. Desimal: Jurnal Matematika, 1(1), 15. https:/ / doi.org/10.24042/ djm.v1i1.1907

Supriadi, Arisetyawan, A., \& Tiurlina. (2016). Mengintegrasikan Pembelajaran Matematika Berbasis Budaya Banten Pada Pendirian Sd Laboratorium UPI Kampus Serang. Mimbar Sekolah Dasar, 3(1), 1-18. https:/ / doi.org/10.17509/mimbar-sd.v3i1.2510

Supriyadi, Palittin, I. D., \& Sari, D. K. (2020). Concept of Sound in Tifa as Papua ' s Contextual Learning Media. 3rd International Conference on Innovative Research Across Disciplines (ICIRAD 2019), 394(Icirad 2019), 391-396. Google Scholar.

Syafitri, Q., Mujib, M., Netriwati, N., Anwar, C., \& Wawan, W. (2018). The Mathematics Learning Media Uses Geogebra on the Basic Material of Linear Equations. Al-Jabar: Jurnal Pendidikan Matematika, 9(1), 9. https:/ / doi.org/10.24042/ ajpm.v9i1.2160

Ulum, B. (2018). Etnomatematika Pasuruan: Eksplorasi Geometri Untuk Sekolah Dasar Pada Motif Batik Pasedahan Suropati. Jurnal Review Pendidikan Dasar: Jurnal Kajian Pendidikan Dan Hasil Penelitian, 4(2), 686. https:/ / doi.org/10.26740/jrpd.v4n2.p686-696

Widada, W., Herawaty, D., \& Lubis, A. N. M. T. (2018). Realistic mathematics learning based on the ethnomathematics in Bengkulu to improve students' cognitive level. Journal of Physics: Conference Series, 1088. https:/ / doi.org/10.1088/1742-6596/1088/1/012028

Willis, D. G., Sullivan-Bolyai, S., Knafl, K., \& Cohen, M. Z. (2016). Distinguishing features and similarities between descriptive phenomenological and qualitative description research. Western journal of nursing research, 38(9), 1185-1204. https:/ / doi.org/10.1177/0193945916645499

Yeni, E. mukhlesi. (2011). Pemanfaatan Benda-Benda Manipulatif Untuk Meningkatkan Pemahaman Konsep Geometri Dan Kemampuan Tilikan Ruang Siswa Kelas V Sekolah Dasar. 1, 63-75. http://jurnal.upi.edu/file/7- 
Malind-Papua Ethnomathematics: Kandara Musical Instrument Learning Media for Geometry Concepts in Elementary School

Ety_Mukhlesi_Yeni.pdf. Google Scholar.

Zaenuri, \& Dwidayati, N. (2018). Exploring ethnomathematics in Central Java.

Journal of Physics: Conference Series, 983(1). https://doi.org/10.1088/17426596/983/1/012108

Copyright Holder :

(C) Fredy, F., Halimah, L., \& Hidayah, Y. (2020)

First Publication Right :

(C) Jurnal Iqra' : Kajian Ilmu Pendidikan

This article is under:

()(1) (2) 